\title{
To Family, Friends, and Colleagues of the Late Dr. Ben Agger
}

\author{
Jason E. Shelton
}

The faculty, staff, and students who knew and had the pleasure of working with Dr. Ben Agger miss him dearly. His long and distinguished career spanned four decades during which he published more than 20 books and 30 peer-reviewed research articles. Ben left an indelible mark on the American academy. His work forged new areas of inquiry, inspired vigorous debate (in various outlets, including the American Sociological Review- the flagship journal of the American Sociological Association), and helped to galvanize a new generation of scholars. He was also a well-known public intellectual who often published op-eds and granted interviews to major media outlets.

Ben's research addressed a wide range of established and cutting-edge topics from political/social movements and the development of American capitalism, to our nation's obsession with fast food and text messaging. His perspective on these topics was informed by his deeper interest in Critical Theory. As an undergraduate student, Ben's intellectual fire was lit by writings from classical theorists such as Marx, Hegel, and Adorno. As a graduate student, he was active in various writing groups that addressed postmodernism, political economy, and cultural studies. Consequently, much of his career was devoted to challenging narrow views of "science" (e.g., those that focused exclusively on empiricism), and championing the broader role that social theory should play in improving the human condition.

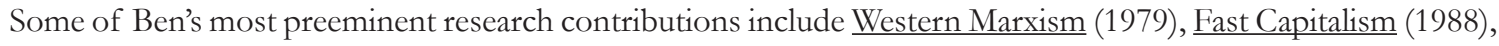
Cultural Studies as Critical Theory (1992), and Speeding Up Fast Capitalism (2004). Each of these books-as well as many others - were warmly received and discussed in rigorous, peer-reviewed outlets. I asked Robert J. Antonio, a leading theorist at the University of Kansas and author of Ben's obituary in Critical Sociology, to list some of Ben's most influential works. He stated that, "Some of his work enjoyed wider readership than others, but I don't think any one individual work defines his contribution. Rather, his hefty corpus of work helped sustain, enliven, and broaden the Critical Theory tradition." This endorsement is buttressed by the fact that typing "Ben Agger" in the search box on Jstor, the leading digital repository for scholarly research, produces 781 results that cover 32 pages of his articles, books reviews, and research papers that reference Ben's work. Leading scholars across various fields of studyincluding Norman Denzin and Charles Lemert—reviewed Ben's books in preeminent publications.

Finally, Ben's success as a researcher reaped benefits that he was able to share with other scholars. In 1999, he founded UT Arlington's Center for Theory, which hosts seminars aimed fostering dialogue between the social sciences and humanities. He also established this publication, Fast Capitalism, a peer-reviewed journal that is housed in the Center and publishes interdisciplinary works on a wide range of contemporary social issues. And above all of the aforementioned, Ben was a great person. He lived every day to its fullest with vision, integrity, passion, commitment, and kindness. I am proud to have called him my friend.

He's gone but will never be forgotten. 
